\title{
THE DIVERSITY OF CUCULIFORM AND PICIFORM SPECIES IN PARTLY TRANSFORMED RIPARIAN ZAMBEZI FOREST
}

\author{
Grzegorz Kopij \\ Department of Integrated Environmental Science \\ Ogongo CampusUniversity of Namibia \\ Private Bag 5520 OshakatiNAMIBIA \\ E-mail: g.kopij@unam.na
}

The Diversity of Cuculiform and Piciform Species in Partly Transformed Riparian Zambezi Forest. Kopij, G. - Both cuculiform and piciform species can be used as bioindicators and, to a lesser extent, as umbrella species. A territory mapping method was employed in 2015 to assess their population densities in a riparian forest on the Zambezi River near Katima Mulilo, NENamibia. The forest, c. 280 ha in surface area, was partly transformed by human settlement and croplands. A total of 9 cuculiform and 6 piciform species were recorded. Population densities (male's territories per 100 ha) were assessed as follow: Diederick, Klaas's and Jacobin Cuckoo - each one with 1.1, African Emerald and African Black Cuckoo - each one with 0.7, Red-chested Cuckoo - 0.4; Senegal Coucal - 4.3, White-browed and Coppery-tailed Coucals - each one with 0.7; Bearded Woodpecker - 1.8, Golden-tailed Woodpecker - 1.1, Cardinal Woodpecker - 0.4; Black-collared Barbet - 5.7, Crested Barbet - 0.7, and Yellow-fronted Tinkerbird - 1.8. Both cuculiform and woodpecker species avoided built-up areas in the man-modified riparian forest, while all barbet species appeared to prefer them. Chrysococcyx cuckoos are not territorial in respect to Cuculus/Clamator cuckoos. The latter ones are, however, territorial in respect to other species from the same genera. Coucals display territorialism in regard to members of other species of the genus Centropus.

Key words: bioindicators, Namibia, population densities, territoriality, tropical riparian forests. 


\section{Introduction}

In terms of bird diversity, riparian forests are regarded as ones of the richest habitats in southern Africa (Seymour, Simmons 2008). However, in Namibia, there are only small areas covered with this vegetation along the Zambezi River (Mendelsohn et al., 2009). In addition, most of this vegetation is under a threat of degradation. It is, therefore, important, to undertake studies to show the effect of human activities on all components of this unique ecosystem.

Among birds, cuculiform and piciform species are regarded as indicators of biodiversity (Mikusiński et al., 2001; Virkkala, 2006; Møller et al., 2017; Morelli et al., 2019). The cuculiform species are in a need of numerous bird species which they can parasitize (Møller et al., 2017; Morelli et al. 2019), while woodpeckers and barbets are hole-nesting birds. They excavate holes in trees, breed in these holes and vacate these after breeding. The holes are readily adopted as nesting sites by other bird species (Virkkala, 2006; Mikusiński et al., 2001). They can be, therefore, regarded also as key species, upon which the occurrence of many other bird species depends. It has been shown that the higher is the piciform and cuculiform species diversity, the higher general diversity of all birds and probably other animal groups (Virkkala, 2006; Mikusiński et al., 2001; Møller et al., 2017; Morelli et al., 2019).

In practice, data on the distribution and population densities of these species may be used to determine the location of nature reserve (Caro, 2003; Drever et al., 2008). The exact site and boundaries of a proposed reserve can be selected using species that are most demanding on resources, such as cuculiform and piciform birds. By conserving these species in a given area, it should be possible to conserve other species as well.

So far, no attempts have been, however, made to assess population densities of these species in sub-Saharan Africa (Fry et al., 1982-2004; Hockey et al., 2005). The purpose of this study was to partly fill this gap in our knowledge. It reports on population densities of both cuculiform and piciform birds in a habitat in southern Africa, regarded as one of the richest in terms of avian diversity (Seymour, Simmons, 2008; Chittenden et al., 2016).An attempt is also taken to evaluate these birds as bioindicators and umbrella species.

\section{Material and methods}

The study area was located in the Zambezi Valley near Katima Mulilo in the Zambezi Region, NE Namibia. The study area comprised a forest stretching between the river and the international road from Zambia through Katima Mulilo to Botswana, laying on the left bank between the Wenela Bridge and the Zambezi River

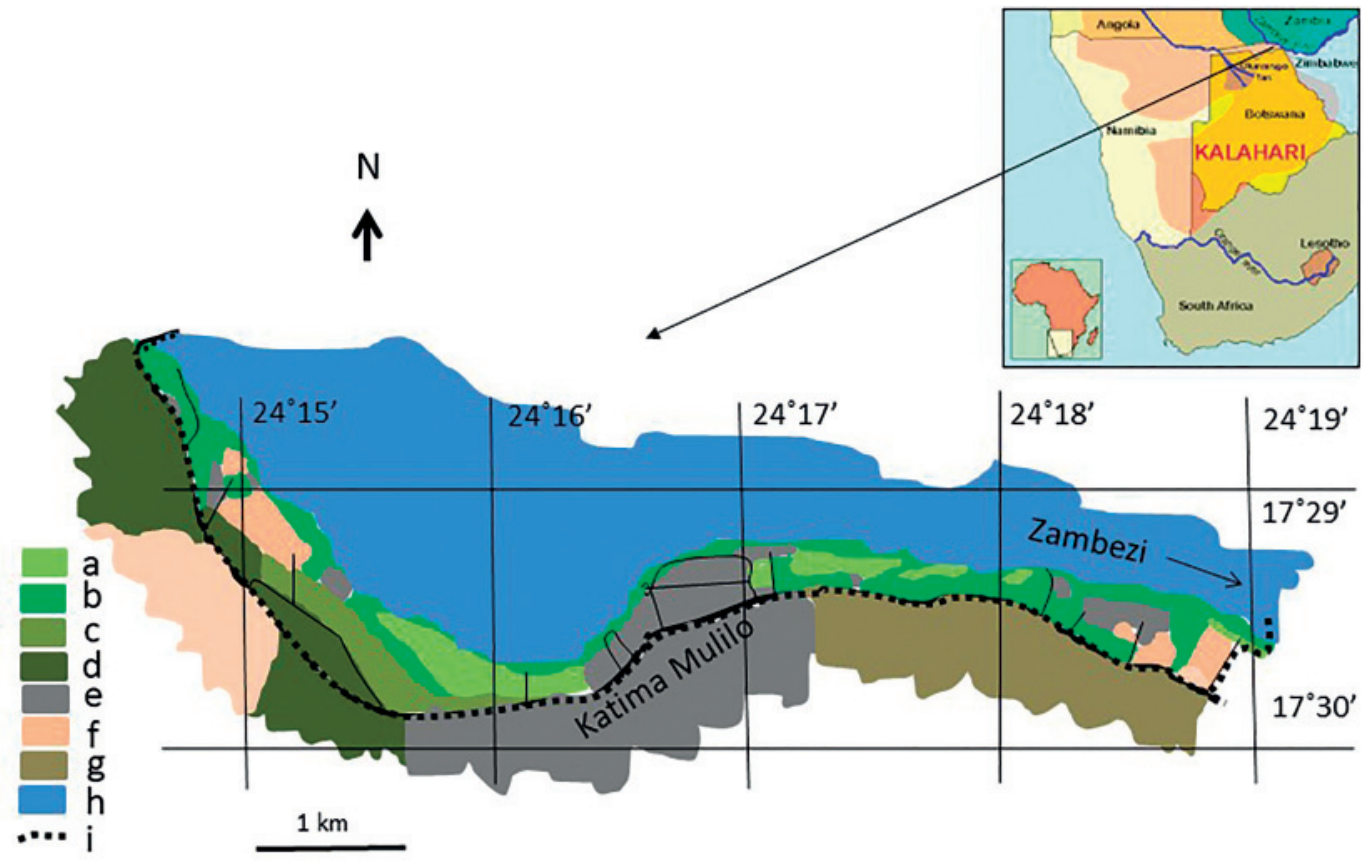

Fig. 1. Location of the study area. Explanations: a — grassland (flooded area); b - Zambezi riparian forest; c - Colophospermum mopane forest; $\mathrm{d}$ - Kalahari Woodland; e - arable land; f - urbanized built-up areas; $\mathrm{g}$ - rural areas; $\mathrm{h}$ - Zambezi River; i - border of the study area. 
lodge (fig. 1). It is $7 \mathrm{~km}$ long and $200-700 \mathrm{~m}$ wide $(x=$ c. $400 \mathrm{~m})$. The approximate surface area of the study area is therefore c. 280 ha.

The natural vegetation is classified as Riparian Zambezi Forest (Mendelsohn et al., 2009). It is composed of large trees such as African Teak (Pterocarpus angolensis), Albizia (Albizia spp.), Apple Leave (Lonchocarpus nelsii), Baobab (Adansonia digitata), Burkea (Burkea africana), Combretum (Combretum spp.), Camel-thorn (Acacia erioloba), Corkwoods (Commiphora spp.), False Mopane (Guibourtia coleospermum), Jackal Berry (Diospyros mespiliformis), Knob-thorn (Acacia nigrescens), Makalani Palm (Hyphaene petersiana), Manketti (Schinziophyton rautanenii), Marula (Sclerocarya birrea), Mopane (Colophospermum mopane), Pod Mahogany (Afzelia quanzensis), Silver Cluster-leaf (Terminalia sericea), Sausage Tree (Kigelia africana), Sycomore Fig (Ficus sycomorus), White Bauhinia (Bauhinia petersiana), and Zambezi Teak (Baikiaea plurijuga) (figs 2 and 3).

The forest is interlaced with pans covered with grass and sedges flooded almost on yearly basis. About $1 / 4$ of the land is converted into croplands and human infrastructure, but large trees usually remain even in these converted areas.

The mean annual temperature for Katima Mulilo is $21^{\circ} \mathrm{C}$. The mean maximum temperature during the hottest month (September) is $35^{\circ} \mathrm{C}$; the mean minimum temperature during the coldest month (July) is $3{ }^{\circ} \mathrm{C}$. In the most humid month (February) the humidity is $80-90 \%$, and only $10-20 \%$ in the least humid month

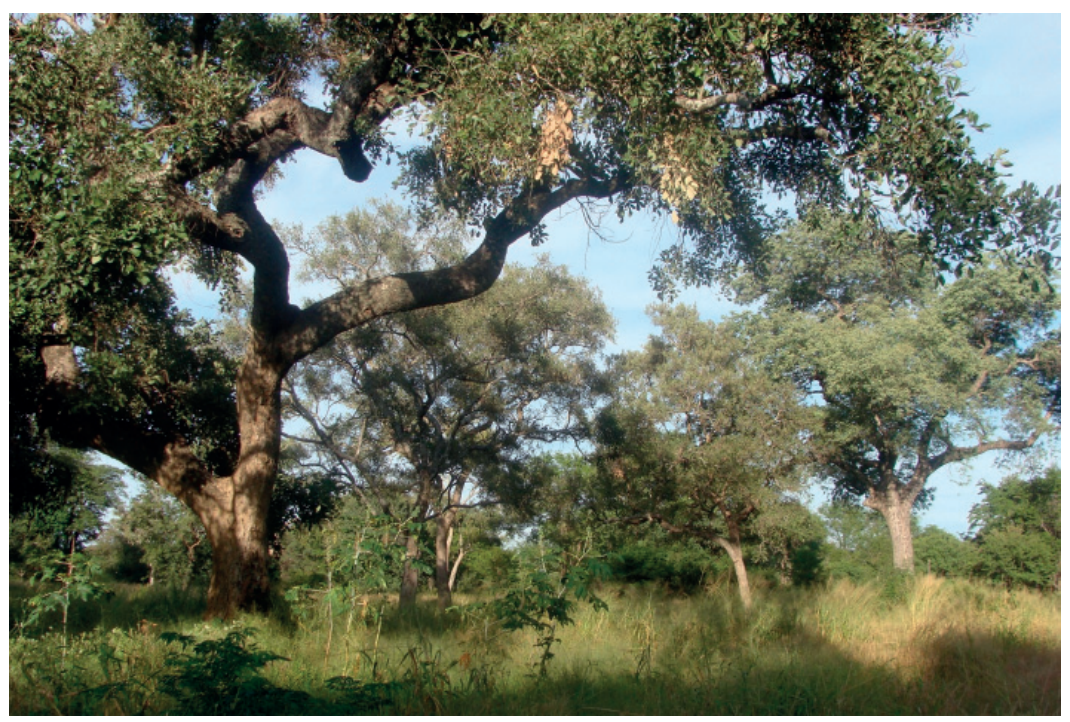

Fig. 2. Zambezi forest dominated by Lonchocarpus trees.

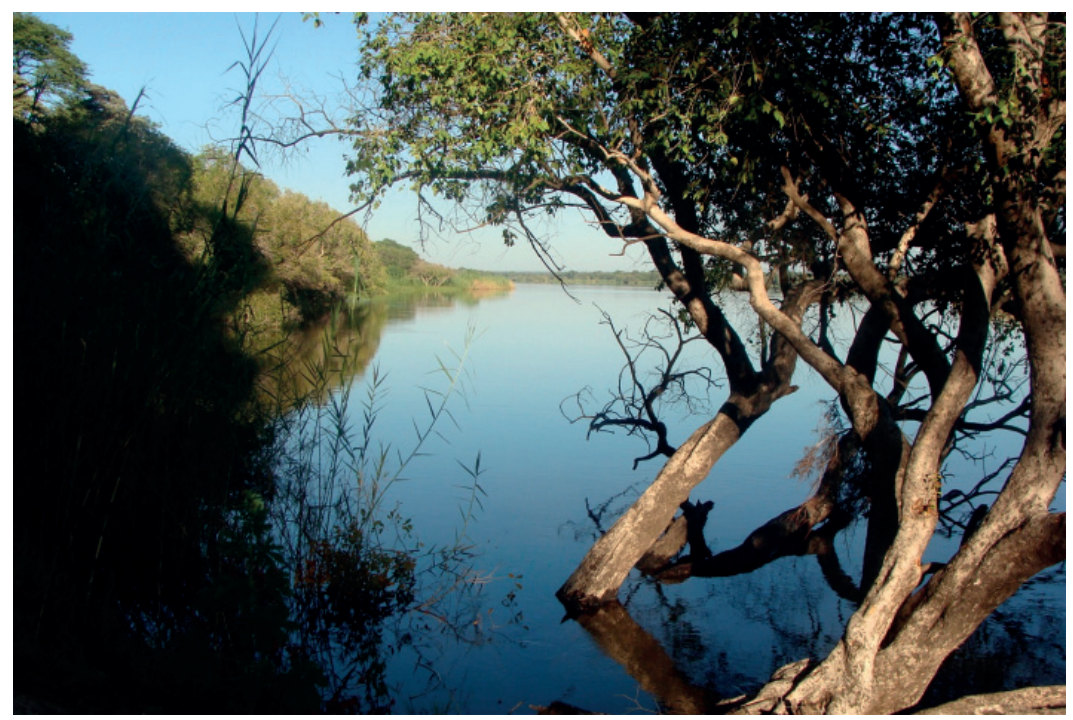

Fig. 3. Zambezi forest fringing Zambezi River. 


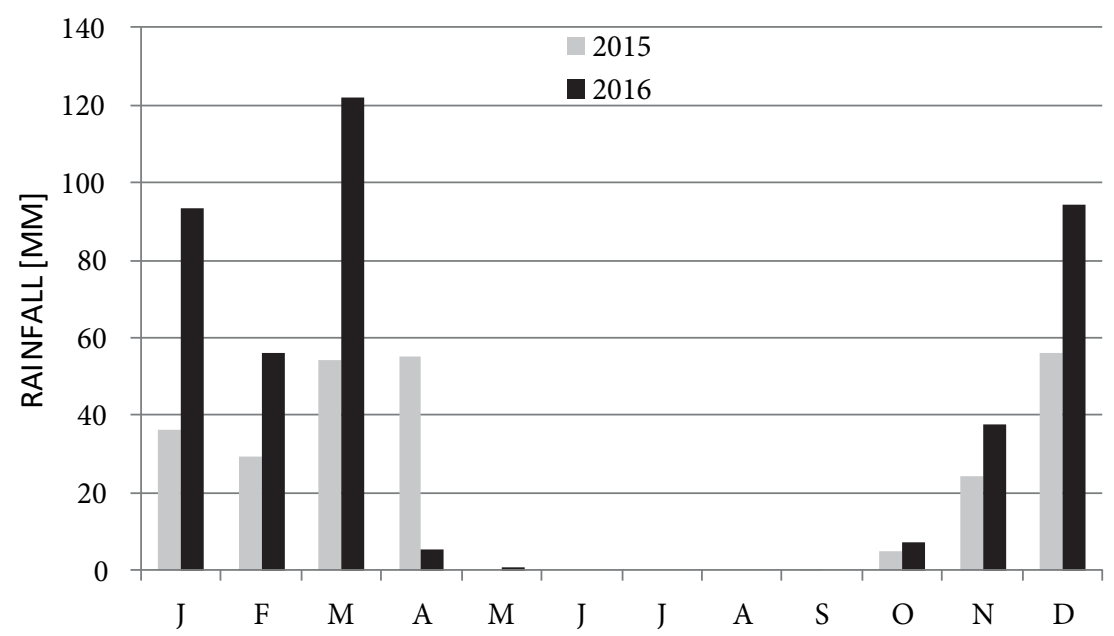

Fig. 4. Monthly rainfall in Katima Mulilo in 2014 and 2015.

(September). The mean annual rainfall is c. $700 \mathrm{~mm}$, the highest in Namibia. Median annual rainfall is 550$600 \mathrm{~mm}$. Most of the rains fall between November and March (fig. 4).

A territory mapping method (Bibby et al., 2012; Sutherland, 1996) has been employed to assess the population densities of all cuculiform and piciform species. The study area was divided into six sections. Birds were counted in each of the sections in one morning. So, six mornings were devoted to cover the whole study area. Such complete coverage was achieved four times in 2015, one complete survey was achieved in each of the following months of 2015: August, September, October and November. During each count, all cuculiform and piciform birds seen or heard were plotted on a map 1: 500. Special attention was paid to birds showing territorial behaviour or breeding display. Also records of two or three simultaneously calling males were important in interpreting the results. A bird or pair of the same species recorded at the same site at least in two out of the four months was interpreted as residential/breeding/territorial (following Bibby et al., 2012).

\section{Results}

In total, sixcuculiform and six piciform species were recorded. Among the Cuculiformes, three Chrysococcyx, three Centropus, two Cuculus, and one Clamator species were recorded. Piciformes were represented by three woodpecker (Picidae) and three barbet (Lybiidae) species (tables 1, 2; figs 5-8). Three cuckoo species were equally numerous: Diederick (Chrysococcyx caprius (Boddaert, 1783)), Klaas's (Chrysococcyx klaas (Stephens, 1815)) and Jacobin (Clamator jacobinus (Boddaert, 1783)). For each of them, three occupied male's territories (1.1 territories per $100 \mathrm{ha}$ ) were recorded (table 1, fig. 5). Two other cuckoo species, namely the African Emerald Cuckoo (Chrysococcyx cupreus (Shaw, 1792)) and African Black Cuckoo (Cuculus clamosus Latham, 1801) held two territories each (0.7 territory per $100 \mathrm{ha}$ ), and there was also one territory of the Red-chested Cuckoo (Cuculus solitarius Stephens, 1815). The Senegal Coucal (Centropus senegalensis (Linné, 1766)) was by far the most numerous coucal species, with 12 established territories (4.3 territories per $100 \mathrm{ha}$ ). The White-browed (Centropus superciliosus, Hemprichet Ehrenberg 1833) and Copperytailed Coucal (C. cupreicaudatus Reichenow, 1896) each had established two territories (fig. 6). There were therefore 14 territories of cuckoos (Cuculidae) and 16 territories of coucals (Centropidae). The overall density of territories held by the cuculiform birds was therefore 10.7 established male territories per 100 ha (table 1).

Among woodpeckers, the Bearded Woodpecker (Dendropicos namaquus (Lichtenstein, 1793)) was the most numerous, breeding at a density of 1.8 pairs per 100 ha. The Goldentailed Woodpecker (Campethera abingoni (Smith, 1836)) reached a density of 1.1, while the Cardinal Woodpecker (Dendropicos fuscescens (Vieillot, 1818)) nested at a density of 0.4 
Table 1.Population densities of cuculiform species in a Zambezi forest ( $280 \mathrm{ha})$

\begin{tabular}{l|c|c|c}
\hline \multicolumn{1}{c|}{ Species } & $\begin{array}{c}\text { Number of } \\
\text { territories }\end{array}$ & $\begin{array}{c}\text { Density } \\
\text { (territ./100 ha) }\end{array}$ & Dominance (\%) \\
\hline Cuckoos (Cuculidae) & $(14)$ & $(5.0)$ & $(46.7)$ \\
Diederick Cuckoo & 3 & 1.1 & 10.0 \\
Klaas's Cuckoo & 3 & 1.1 & 10.0 \\
African Emerald Cuckoo & 2 & 0.7 & 6.7 \\
Jacobin Cuckoo & 3 & 1.1 & 10.0 \\
African Black Cuckoo & 2 & 0.7 & 6.7 \\
Red-chested Cuckoo & 1 & 0.4 & 3.3 \\
Coucals (Centropidae) & $(16)$ & $(5.7)$ & $(53.3)$ \\
Senegal Coucal & 12 & 4.3 & 40.0 \\
White-browed Coucal & 2 & 0.7 & 6.7 \\
Coppery-tailed Coucal & 2 & 0.7 & 6.7 \\
Total & 30 & 10.7 & 100 \\
\hline
\end{tabular}

Table 2. Population densities of woodpecker and barbet species in a Zambezi forest ( $280 \mathrm{ha})$

\begin{tabular}{l|c|c|c}
\hline \multicolumn{1}{c|}{ Species } & Number of pairs & $\begin{array}{c}\text { Density (pairs/100 } \\
\text { ha) }\end{array}$ & Dominance (\%) \\
\hline Woodpeckers (Picidae) & $(9)$ & $(3.2)$ & $(28.1)$ \\
Bearded Woodpecker & 5 & 1.8 & 15.6 \\
Golden-tailed Woodpecker & 3 & 1.1 & 9.4 \\
Cardinal Woodpecker & 1 & 0.4 & 3.1 \\
Barbets (Lybiidae) & $(23)$ & $(8.2)$ & $(71.9)$ \\
Black-collared Barbet & 16 & 5.7 & 50.0 \\
Crested Barbet & 2 & 0.7 & 6.3 \\
Yellow-fronted Tinkerbird & 5 & 1.8 & 15.6 \\
Total & 32 & 11.4 & 100 \\
\hline
\end{tabular}

(table 2). Among barbets, by far the most numerous was the Black-collared Barbet (Lybius torquatus (Dumont, 1816)) (fig. 9) nesting at a density of 5.7 pairs per 100 ha. The Yellowfronted (Tinkerbird (Pogoniulus chrysoconus (Temminck, 1832)) reached a density of 1.8 pairs per 100 ha, while the Crested Barbet (Trachyphonus vaillantii Ranzani, 1821) 0.7 pair per 100 ha (table 2, fig. 10).

The proportion between occupied territories of cuculiform and piciform birds in the riparian forest was equal $(0.48: 0.52 ; \mathrm{n}=62)$, as was also the proportion between occupied

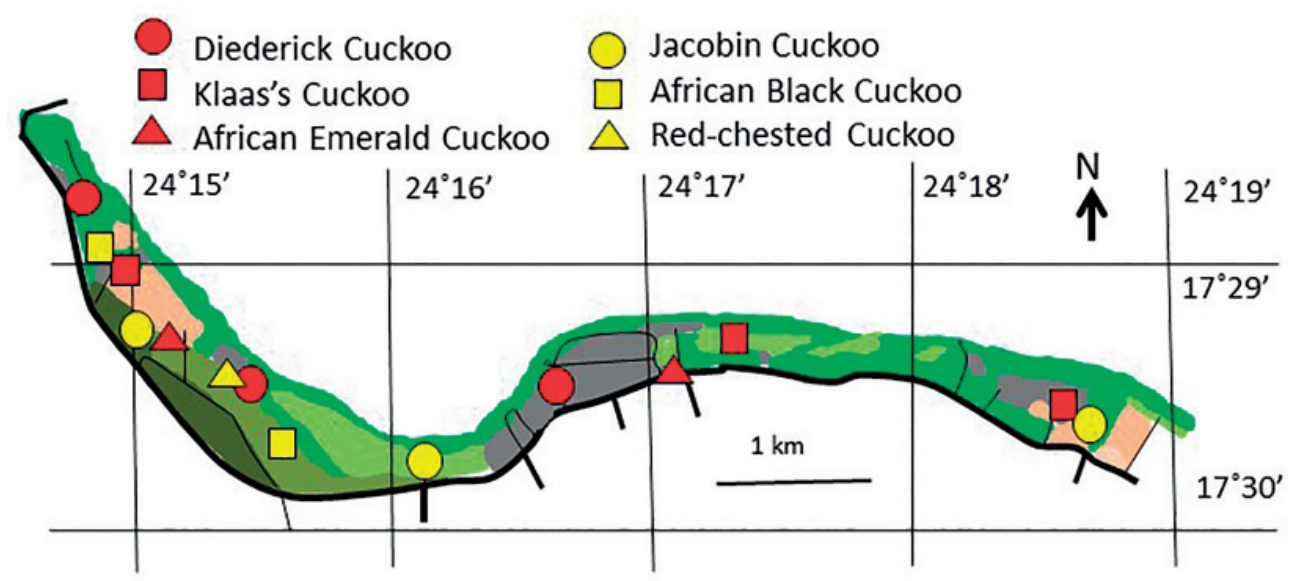

Fig. 5. Distribution of occupied male territories of cuckoos in Zambezi riparian forest. 


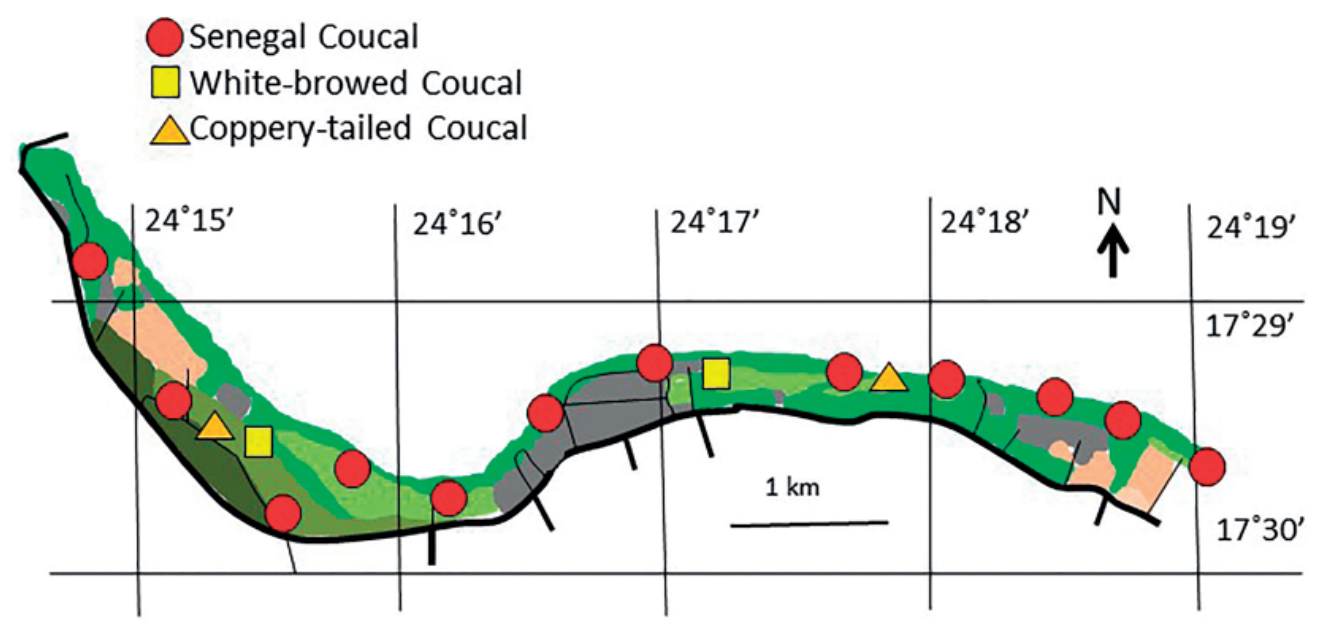

Fig. 6. Distribution of occupied male territories of coucals in Zambezi riparian forest.

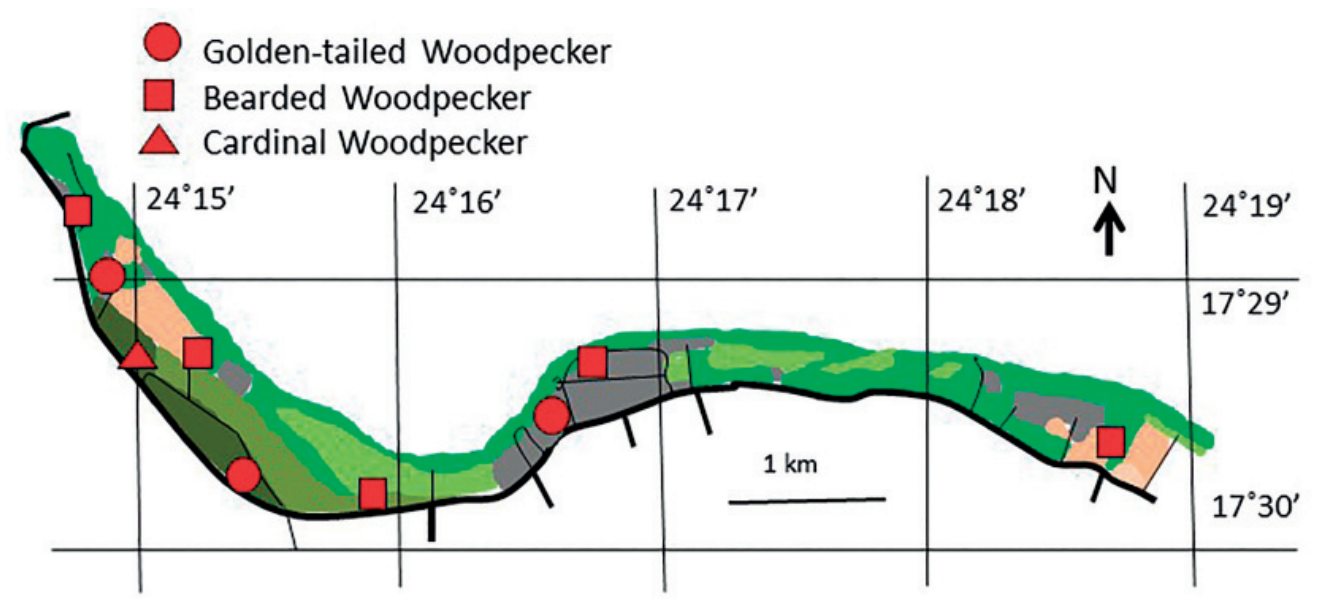

Fig. 7. Distribution of breeding pairs of woodpeckers in Zambezi riparian forest.

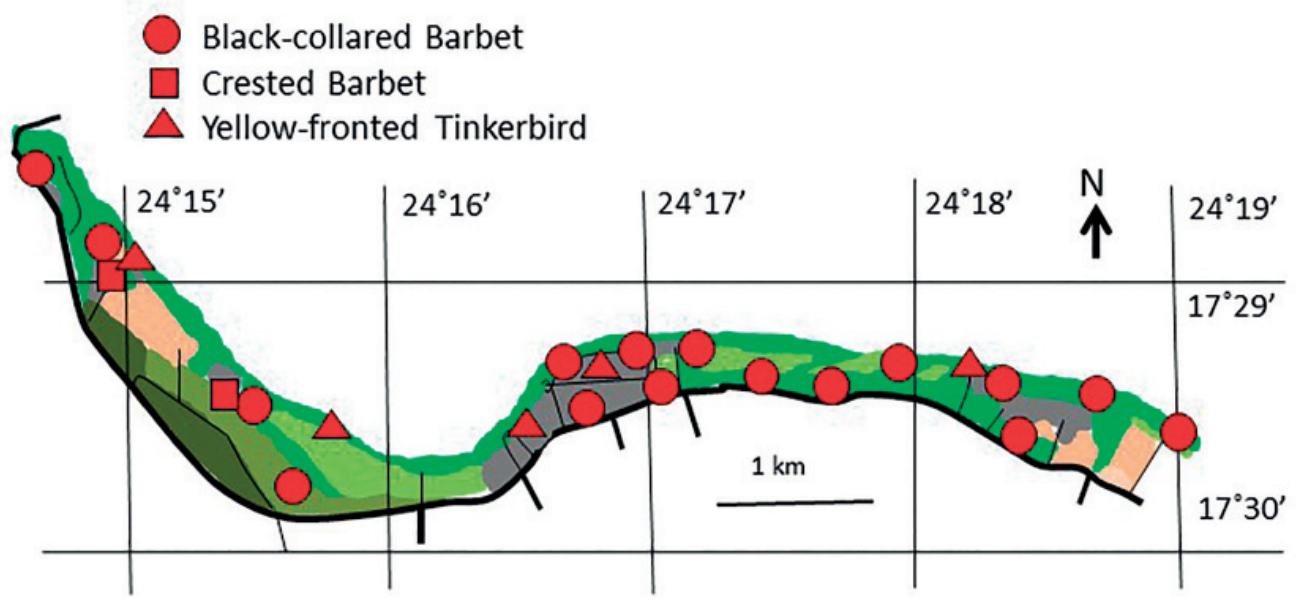

Fig. 8. Distribution of breeding pairs of barbets in Zambezi riparian forest. 
territories of cuckoos and coucals $(0.47$ : $0.53 ; \mathrm{n}=30$ ). However the proportion between woodpecker and barbet breeding pairs was skewed $(0.21: 0.79$; $\mathrm{n}=29$ ).

A few other species were recorded in a close proximity to the study area: Acacia Pied Barbet (Tricholaema leucomelas (Boddaert, 1783)), Levaillant's Cuckoo (Clamator levaillantii (Swainson, 1829)) and Great Spotted Cuckoo (Clamator glandarius (Linné, 1758)).

\section{Discussion}

Both cuculiform and woodpecker species avoided built-up areas in the man-modified riparian forest, while all barbet species appeared to prefer them (fig. 8). In the built-up area, there are probably scarcity of old trees as feeding and nesting sites for woodpeckers, but abundance of fruit trees such as Ficus spp., mango (Mangifera indica), papaya (Carica papaya) and others which provide fruits for barbets.

It appears from fig. 5 that Chrysococcyx cuckoos are not territorial in respect to Cuculus/Clamator cuckoos. The latter ones are however territorial in respect to other species from the same genera. Fig. 64 suggests that coucals display territoriality in regard to members of other species of the genus Centropus (cf. Hockey et al., 2005).

The diversity of cuculiform and piciform species recorded in the riparian forest near Katima Mulilo is relatively high (9 and 6 species respectively). In the neighbouring town of Katima Mulilo, well-endowed with indigenous and exotic trees (highly transformed riparian forest), the number of cuculiform was 5 , that of piciform - also 5 (Kopij, 2016). In the Kalahari woodland (12 km long transect) in the same Zambezi Region - only one cuculiform species, 3 woodpecker and 2 barbet species were recorded (Kopij, 2017). In urbanized woodland in Pretoria, two woodpecker species (2 pairs/100 ha), three cuculiform (3 male territories/100 ha) and one

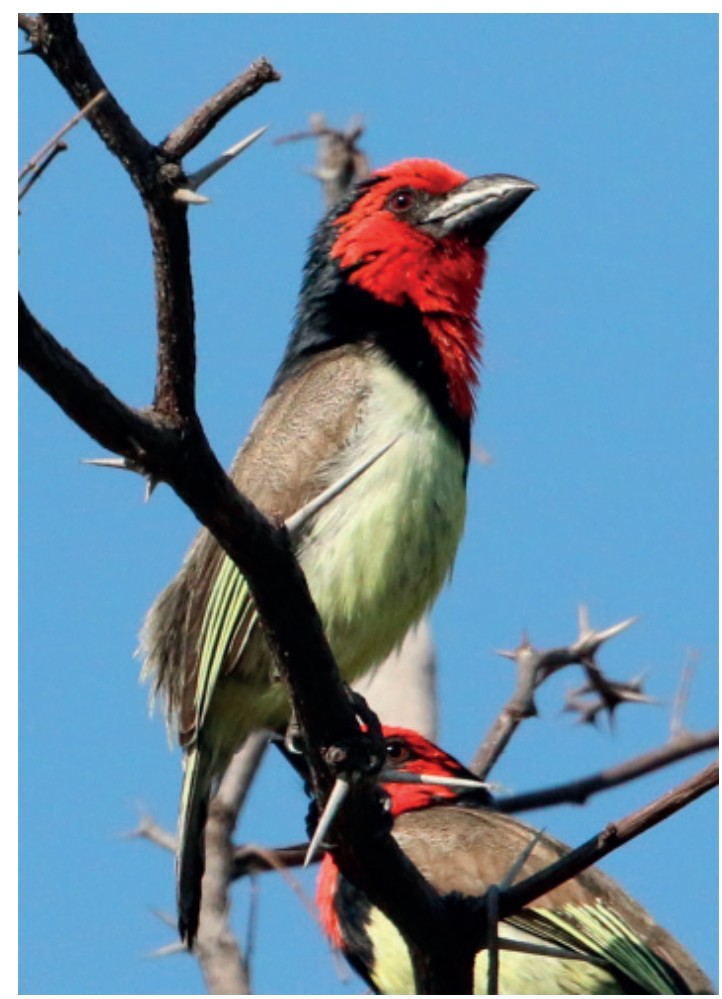

Fig. 9. The Black-collared Barbet.

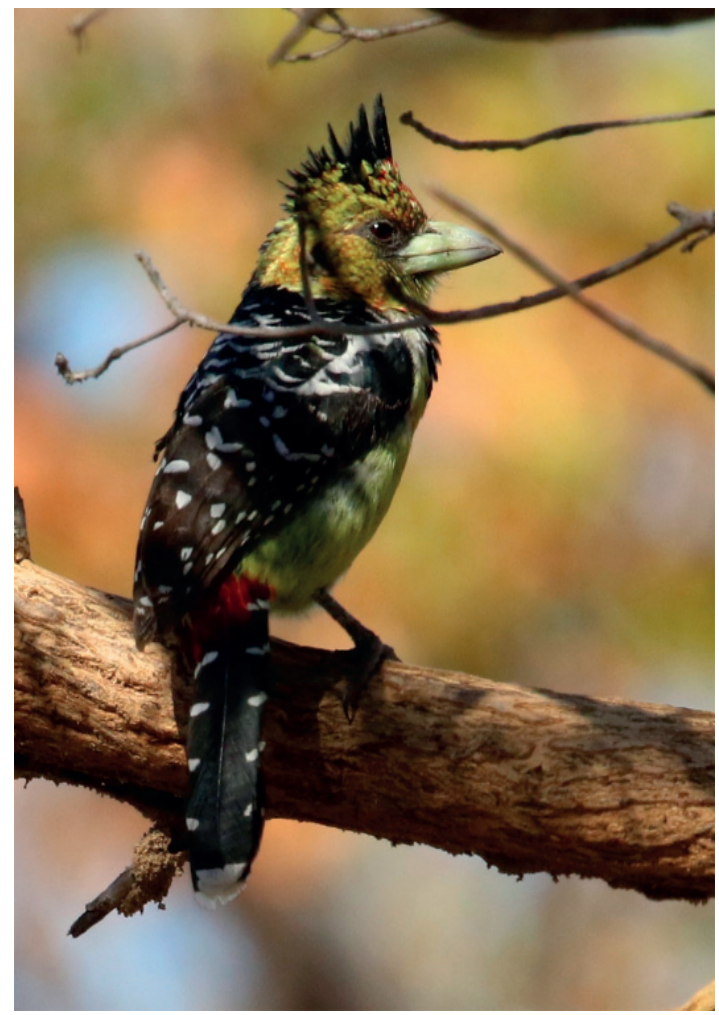

Fig. 10. The Crested Barbet. 
Table 3. Number of cuculiform and piciform species in various natural and urbanized woodlands in southern Africa

\begin{tabular}{|c|c|c|c|c|c|}
\hline Habitat and locality & Cuckoos & Coucals & Woodpeckers & Barbets & Source \\
\hline $\begin{array}{l}\text { Riparian Forest, } \\
\text { Zambezi Region, NE Namibia }\end{array}$ & 6 & 3 & 3 & 3 & This study \\
\hline $\begin{array}{l}\text { Urbanized riparian forest, } \\
\text { Katima Mulilo, NE Namibia }\end{array}$ & 3 & 2 & 2 & 3 & Kopij, 2014 \\
\hline $\begin{array}{l}\text { Urbanized woodland, Kasane, } \\
\text { NE Botswana }\end{array}$ & 2 & 1 & 1 & 2 & Kopij, 2018 b \\
\hline $\begin{array}{l}\text { Kalahari Woodland, } \\
\text { NE Namibia }\end{array}$ & 1 & 0 & 3 & 2 & Kopij, 2016 \\
\hline $\begin{array}{l}\text { Mopane woodland, Ogongo, } \\
\text { north-central Namibia }\end{array}$ & 2 & 0 & 1 & 2 & Kopij, 2018 a \\
\hline $\begin{array}{l}\text { Urbanized woodland, Pretoria, } \\
\text { South Africa }\end{array}$ & 3 & 0 & 2 & 1 & Parker, 2013 \\
\hline $\begin{array}{l}\text { Urbanized woodland, } \\
\text { Bloemfontein, South Africa }\end{array}$ & 2 & 0 & 0 & 3 & Kopij 2001a, 2015 \\
\hline $\begin{array}{l}\text { Urbanized woodland, Roma, } \\
\text { Lesotho }\end{array}$ & 3 & 1 & 1 & 2 & Kopij, 2001 b \\
\hline Maseru, Lesotho & 3 & 0 & 1 & 2 & Kopij 2000 \\
\hline $\begin{array}{l}\text { Urbanized artificial oasis } \\
\text { Swakopmund, Namibia }\end{array}$ & 0 & 0 & 0 & 0 & Kopij, 2018 c \\
\hline
\end{tabular}

barbet species (the Crested Barbet breeding at a density of 14 pairs/100 ha) were recorded (Parker, 2013). In general, the numbers of cuculiform and piciform species in southern Africa gradually decline from the east to the west and from the north to the south (table 3 ). This pattern follows probably the overall avian species diversity in Namibia.

In an urbanized rain forest in Liberia (fragments of rain forests mixed with secondary growth, cultivated fields and orchards), the number of cuculiform species was 5, that of piciform (woodpeckers and barbets) species - also 5, while in the neighbouring natural rainforest the number was 2 and 4 respectively (Kofron, Chapman, 1995). Cuculiform, and to a lesser extent piciform species, may therefore benefit from modification of closed forest into more open habitat (a mosaic of the forests, arable fields, orchards etc.). Among piciform, the barbets may benefit from fruit trees, usually present in large number in manmodified habitats. It has been shown that by 'opening' forest, new habitats are often created for savanna inhabiting species. The total number of bird species therefore increases, and the number of cuculids also increases as they have more species to parasitize. This is a good example showing that a high number of cuculiform species may indeed be indicative of high number of bird species, but not necessary it may indicates the high habitat quality or high level of naturalness of habitats. In fact, they may indicate the degree of forest transformation into more 'open' landscape (fragmented forest).

In respect to woodpeckers, it is also true that the number of species and their population densities are in southern Africa higher in more natural forest habitats rather than in man-modified ones. They are dependent on old trees which are usually more common in natural forests.

Therefore, both cuculiform and piciform species can be used as bioindicators and, to a lesser extent, as umbrella species (Mikusiński et al., 2001; Virkkala, 2006; Drever et al., 2008; Møller et al. 2017; Morelli et al., 2019). Since their populations can be reliable monitored, they can help to identify areas of species richness, to delineate specific reserve boundaries, and to encompass populations of co-occurring species within them (Drever et al., 2008).

The Zambezi riparian forest proved to be rich in terms of bird diversity. The high number of cuculiform and piciform bird species recorded in this forest is indicative of this high richness. However, with continuing fragmentation of this forest, the species diversity as well as population densities undergo some changes. 
The overall density of woodpeckers in the riparian forest was probably much higher few decades ago (more old trees) than it is today. The reverse situation could be applicable to barbets (more fruit trees today than in the past). It would be very interesting to monitor their numbers. Further decline in woodpecker densities will indicate further deterioration of the precious riparian forest, while in the same time barbets may even increase their numbers, as more fruit trees may be introduced to this area. In the case of cuculiform species their anticipated increase in numbers may indicate an influx of savanna species to fragmented forest habitat. So, the increase of cuculiform birds will not be indicative of a naturalness of this habitat, rather it may indicate its fragmentation.

Since the Zambezi riparian forests is a marginal biome in Namibia, and it is so rich in terms of biodiversity, it is strongly recommended to increase efforts to protect the remaining natural patches of this habitat in the form of nature reserves.

\section{References}

Bibby, C. J., Burgess, N. D., Hill, D. A., Mustoe, S. 2012. Bird Census Techniques, 2nd ed. Academic Press, London.

Chittenden, H., Davis, G., Weiersbye, I. 2016. Roberts'Bird Guide. John Voelcker Bird Book Fund, Cape Town.

Caro, T. M. 2003. Umbrella species, critique and lesson from East Africa. Animal Conservation, 6, 171-181.

Drever, M., Aitken, K. E. H., Norris, A. R., Martin, K. 2008. Woodpeckers as reliable indicators of bird richness, forest health and harvest. Biological Conservation, 141, 624-634.

Fry, C. H., Stuart, K., Urban, E. 1982-2004. The birds of Africa. Vol. 1-7. Academic Press, Cambridge (MA, USA).

Hockey, P. A. R., Dean, W. R. J., Ryan, P. G., Maree, S., Brickman, B. M., eds. 2005. Roberts' Birds of Southern Africa. John Voelcker Bird Book Fund, Cape Town.

Kofron, C. P., Chapman, A. 1995. Deforestation and bird species composition in Liberia, West Africa. Tropical Zoology, 8 (2), 239-256.

Kopij, G. 2000. Birds of Maseru. NUL Journal of Research (Roma, Lesotho), 8, 104-151.

Kopij, G. 2001 a. Atlas of Birds of Bloemfontein. Department of Biology, National University of Lesotho/Free State Bird Club. (Lesotho)/Bloemfontein (RSA).

Kopij, G. 2001 b. Birds of Roma Valley, Lesotho. Roma. Department of Biology, National University of Lesotho, Roma (Lesotho).

Kopij, G. 2014. Avian Assemblages in Urban Habitats in North-central Namibia. International Science \& Technology Journal of Namibia, 3 (1), 64-81.

Kopij, G. 2015. Avian diversity in an urbanized South African grassland. Zoology \& Ecology, 25 (2), 87-100.

Kopij, G. 2016. Birds of Katima Mulilo town, Zambezi Region, Namibia. International Science \& Technology Journal of Namibia, 7, 85-102.

Kopij, G. 2017. Structure of avian assemblages in Zambezian Baikiaeae woodlands, northern Namibia. Zoology \& Ecology, 27, 1-10.

Kopij, G. (2018 c): Population density, and community structure of birds breeding in Mopane Savanna of the Ogongo Game Park, north-central Namibia. International Journal of Science \& Technology of Namibia, $12,117-134$.

Kopij, G. 2018 b. Atlas of birds of Kasane town, NE Botswana. Babbler, 64, 3-15.

Kopij, G. 2018 c. Provisional atlas of breeding birds of Swakopmund in the coastal Namib Desert. Lanioturdus, $51(2), 2-12$.

Mendelsohn, J., Jarvis, A., Roberts, C., Robertson, T. 2009. Atlas of Namibia. A Portrait of the Land and its People. Sunbird Publishers, Cape Town.

Mikusiński, G., Gromadzki, M., Chylarecki, P. 2001. Woodpeckers as indicators of forest bird diversity. Conservation Biology, 15, 208-217.

Møller, A. P., Morelli, F., Benedetti, Y., Mousseau, T., Su. T., Zhou, B., Tryjanowski, P., Liang, W. 2017. Multiple species of cuckoos as superior predictors of bird species richness in Asia. Ecosphere, 8 (11), e02003.10.1002/ec2.2003.

Morelli, F., Benedetti, Y., Moravec, D., Jerzak, L., Tryjanowski, P., Liang, W., Møller, A. P. 2019. Global congruence between cuckoo species richness and biodiversity hotspots. Biodiversity Conservation, 232, $28-34$.

Parker, V. 2013. Population densities of woodland bird species at the Pretoria National Botanical Garden. Ornithological Observations, 4, 94-103.

Sutherland, W. J. 1996. Ecological Census Techniques: a handbook. Cambridge University Press, Cambridge (U.K.). 
Seymour, C. L., Simmons, R. E. 2008. Can severely fragmented patches of riparian vegetation still be important for arid-land bird diversity. Journal of Arid Environment, 72, 2275-2281.

Virkkala, R. 2006. Why study woodpeckers in forest ecosystem. Annales Zoologici Fennici, 43, 82-85.

Received 8 July 2019

Accepted 25 October 2019 